\title{
The Archaeology of World War II Japanese Stragglers on the Island of Guam and the Bushido Code
}

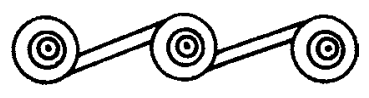

\author{
BOYD DIXON, LAURA GILDA, AND LON BULGRIN
}

\section{GUAM ENVIRONMENT, EARLY HISTORY, AND WORLD WAR II}

With a tOTAL LAND MASS OF approximately 539 square kilometers (sq km), Guam is the largest of the Mariana Islands and the largest island in Micronesia. It is situated near latitude $13^{\circ} 28^{\prime}$ north and longitude $144^{\circ} 45^{\prime}$ east, approximately $2414 \mathrm{~km}$ (1500 mi) east of the Philippine Islands (Fig. 1). Guam has a humid tropical climate with a temperature range of 20 to 30 degrees Celsius and an annual rainfall of 200$250 \mathrm{~cm}$ (61-76 in.). Although the island experiences its most unstable weather during the second half of the year, tropical storms and typhoons can occur at any time (Lobban and Schefter 1997; Young 1988).

The Mariana Islands were colonized at least 3000 years before European contact. These settlers were probably the ancestors of the Chamorro people who met Ferdinand Magellan's ship when it made landfall on Guam in 1521 (Bellwood 1979; Russell 1998). Guam was the bastion of colonial Spanish rule and culture in the archipelago from 1668 until the Spanish-American War in 1898 (Rogers 1995). The island was ceded by Spain to the United States at the end of the war. The American Navy assumed responsibility for administering Guam for the next 40 years (JennisonNolan 1980; Thompson 1945). Guam's Apra Harbor became a fueling station for U.S. ships, a trans-Pacific cable station, a strategic naval radio station, and a landing strip for Pan American trans-Pacific air clippers flying between San Francisco and Hong Kong. The remaining Mariana Islands were sold by Spain to the Germans in 1899 (Fritz 2001; Russell 1999; Spennemann 1999). At the end of World War I in 1914, the Japanese assumed control of Saipan and the northern Mariana Islands from Germany (Ballendorf and Bartlett 1997; Higuchi 1997, 2000; Peattie 1988). A vibrant sugarcane plantation economy eventually developed on these islands (Dixon 2004).

On December 8, 1941, Japanese planes attacked Apra Harbor and the village of Sumay a few hours after Pearl Harbor in Hawai'i was attacked (Rogers 1995). The

Boyd Dixon is Senior Archaeologist, Cardno TEC, Hagatna, Guam. Laura Gilda is Cultural Resources Specialist, DPW Environmental, Conservation and Restoration Branch, U.S. Army Garrison Hawai'i, Schofield, Hawai'i. Lon Bulgrin is a Cultural Resources Specialist, Naval Facilities Command Marianas, U.S. Naval Base, Guam. 


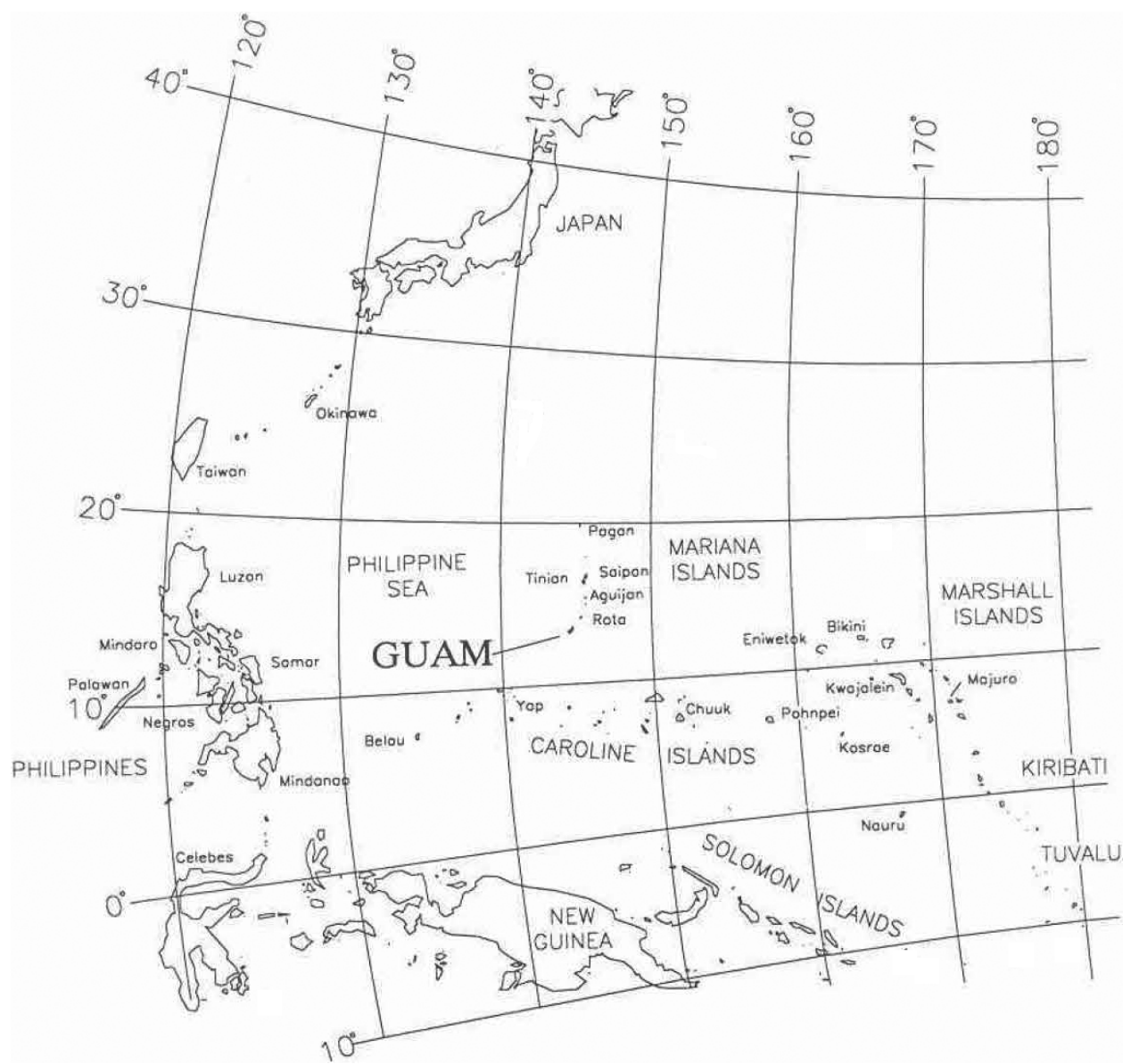

Fig. 1. Location of Guam in the Western Pacific.

American naval commander had only a small force at his command, so he surrendered when Japanese forces landed on Guam on December 10 (Rottman 2004). In early 1942, most Japanese Army units were redeployed to Melanesia; the Japanese Navy assumed control of the island with a garrison of only 300 men. With the increased threat of an American invasion, however, 18,000 Japanese Army units returned to Guam in March 1944. The entire Chamorro population, along with Okinawan and Korean forced labor, was conscripted to build defenses and feed the occupation forces (Denfield 1997, 2002; Peattie 1988). New rice fields were planted under the auspices of the Kaikuntai military office and all civilians were put on shortened rations (Higuchi 2000). Some Chamorros escaped into the rugged jungles to avoid forced labor (Blaz 2008), but when U.S. invasion became imminent, most were captured and put into concentration camps in the interior of the island (Palomo 1984).

On July 8, 1944, 11 U.S. battleships, 24 aircraft carriers, and 390 other ships and aircraft commenced intensive bombardment of Apra Harbor, the Orote airfield, and nearby coastal defenses (Dixon et al. 1999). Underwater demolition teams blew up 
reef and lagoon obstacles off the west coast between July 17 and 19 (Burns 2008). On July 21, the 3rd Marine Division landed on Asan Beach; the Army's 77th Infantry Division and 1st Provisional Brigade landed in Agat the next day (Gailey 1988; Lodge 1954). By July 29, U.S. Marines had retaken their former barracks on Orote Point. On August 10, after all organized resistance had ended and Chamorro civilians were released from the concentration camps, American sovereignty over the island of Guam was proclaimed (O’Donnell 2002). Nearly 54,000 American forces participated in retaking Guam from approximately 18,500 Japanese forces and noncombat construction units (Rogers 1995).

With Chamorro guides, the 3rd Marine Division conducted armed reconnaissance through the rugged limestone interior of the island (Rottman 2004). They pursued Major Sato in the south and Lieutenant Colonel Hideyuki Takeda in what is today called the Naval Ordnance Annex; both commanders had a company of over 60 infantry soldiers. The Japanese infantry and other military stragglers survived on the land by foraging in former Chamorro lanchos (ranches) and U.S. military surplus dumps. Only after the Emperor of Japan broadcast his order to surrender did Takeda and his troops lay down their arms on September 4, 1945 (Gailey 1988). By that time, over 1200 Japanese troops on the island had surrendered, many in response to American broadcasts by bullhorn and aerial distribution of leaflets in Japanese. Individual stragglers continued to hide in the jungles for decades, however (Kahn 1962). The last Japanese soldier from World War II to surrender was Private Shoichi Yokoi, who was captured by Chamorro hunters in 1972, two years after Guam became a U.S. Territory (Hatashin 2009).

\section{JAPAN AND THE CODE OF BUSHIDO}

During the late nineteenth century, when Guam was being wrested from colonial Spain by the United States, the power of the shogun or feudal lords over Japan was also being challenged, in part under pressure from other growing Pacific Rim empires. The Tokugawa shogunate folded in 1868, following American commodore Mathew Perry's uninvited arrival in Edo Bay in 1853 and treaties with Britain and Russia the following year (Brooke 1986). The young emperor Mutsushito and his advisors were restored to power; his reign was called the Meiji or Enlightened One (Meyer 1993). A parliamentary government was created and Japan began to cautiously welcome outside trade and influences (Benfey 2003; Martinez 2004). Having seen the samurai (warrior class) defeated by Western armament and techniques, the new government began rapid expansion of a military force.

The samurai had been guided by Bushido-the Way of the Warrior-a unique code of conduct from feudal Japan combining the stoicism of Buddhism, the contemplation of Zen, the ancestral reverence of Shinto, and the ethical doctrines of Confucius (Nitobe 2006:22). While the political power of the samurai was sharply curtailed during the Meiji era, the Bushido ethic remained a strong undercurrent in traditional sentiment. While today equated primarily with the ethics of combat in Western thought, Bushido in its widest interpretation "held that the interest of the family and of the members thereof is intact,- - one and inseparable" (Nitobe 2006:66). As a national ethic implicitly guiding the behavior of the Japanese people, this code espoused deep loyalty to one's collective ancestors, submission to elder male members of one's family, and devotion to the nation and its leaders. When confronted with adversity 
in life, the individual and the general populace were expected to "bear and face all calamities ... with patience and a pure conscience" (Nitobe 2006:88).

After the death of the Meiji emperor in 1912, during his son Taisho's Great Righteousness reign, the military elite installed a party system of government that fostered an economic boom embracing global mercantilism and military expansion. The Japanese Empire expanded considerably during this period, first by occupying Formosa and invading Manchuria in 1895, then in combat with Russia in 1904, and eventually acquiring Korea as a protectorate in 1905 (Meyer 1993). World War I brought Japan into the Pacific theater of combat as an ally of the British and Americans. Japan profited from this association by inheriting Germany's Micronesian possessions as a mandate in 1918 after the Treaty of Versailles (Ballendorf and Bartlett 1997). It did not obtain ownership of the Siberian and Manchurian railways as the Japanese military wished, however.

After Emperor Taisho died in 1926, his son Prince Hirohito became ruler, starting the Showa or Shining Peace reign (Behr 1989). As a partial response to the suffering Japanese economy during the global depression of the early 1930s, Hirohito's government devised the Greater East Asian Co-Prosperity Sphere to further its commercial and military interests in the broader Pacific (Hane 1982). Economic development of Micronesia presented an opportunity for implementing this new program, since the islands provided a captive source for Japanese industry and raw materials for the next military campaign against China in 1931. Supplementing the few native Chamorro inhabitants in Saipan, Tinian, and Rota, rural farmers from Okinawa (a Japanese protectorate) and recently invaded China and Korea were sent to the Northern Mariana Islands as forced or indentured laborers (Rogers 1995). As noted earlier, Guam remained in American hands until 1941.

Early Japanese successes against the United States and its allies in the Pacific theatre during World War II emboldened the military rank and file, as well as the political elite. These early successes seemed to confirm to the general public that the Japanese military were indeed inheritors of the proud samurai tradition (Ineaga 1978). Only after successive losses in the Marianas and elsewhere, followed by eventual capitulation in 1945, did it become apparent that this belief was misguided. The humiliation of the Japanese military elite was largely of its own making, not the result of disloyalty of the people to their emperor.

Many Japanese soldiers did not surrender in Guam and elsewhere in the Pacific (Fukami and Cross 1969; Jones 1986; Kahn 1962; Onada 1974). They continued to honor the Bushido code, believing that "to rush into the thick of battle and to be slain in it, is easy enough . . but, it is true courage to live when it is right to live, and to die only when it is right to die" (Nitobe 2006:33). Indeed, "for a true samurai to hasten death or to court it, was like cowardice" (Nitobe 2006:88). ${ }^{1}$ Some Japanese soldiers considered surrender a way of courting death, therefore contrary to the Bushido code. They chose to continue hiding in the jungles instead. The archaeology of how these "stragglers" survived is the topic of this article.

\section{ARCHAEOLOGICAL EVIDENCE OF WORLD WAR II JAPANESE STRAGGLERS ON GUAM}

In July 1998, Ogden Environmental and Energy Services, Inc., of Honolulu, Hawai'i, began an archaeological survey for the U.S. Navy of four areas within the U.S. Naval 


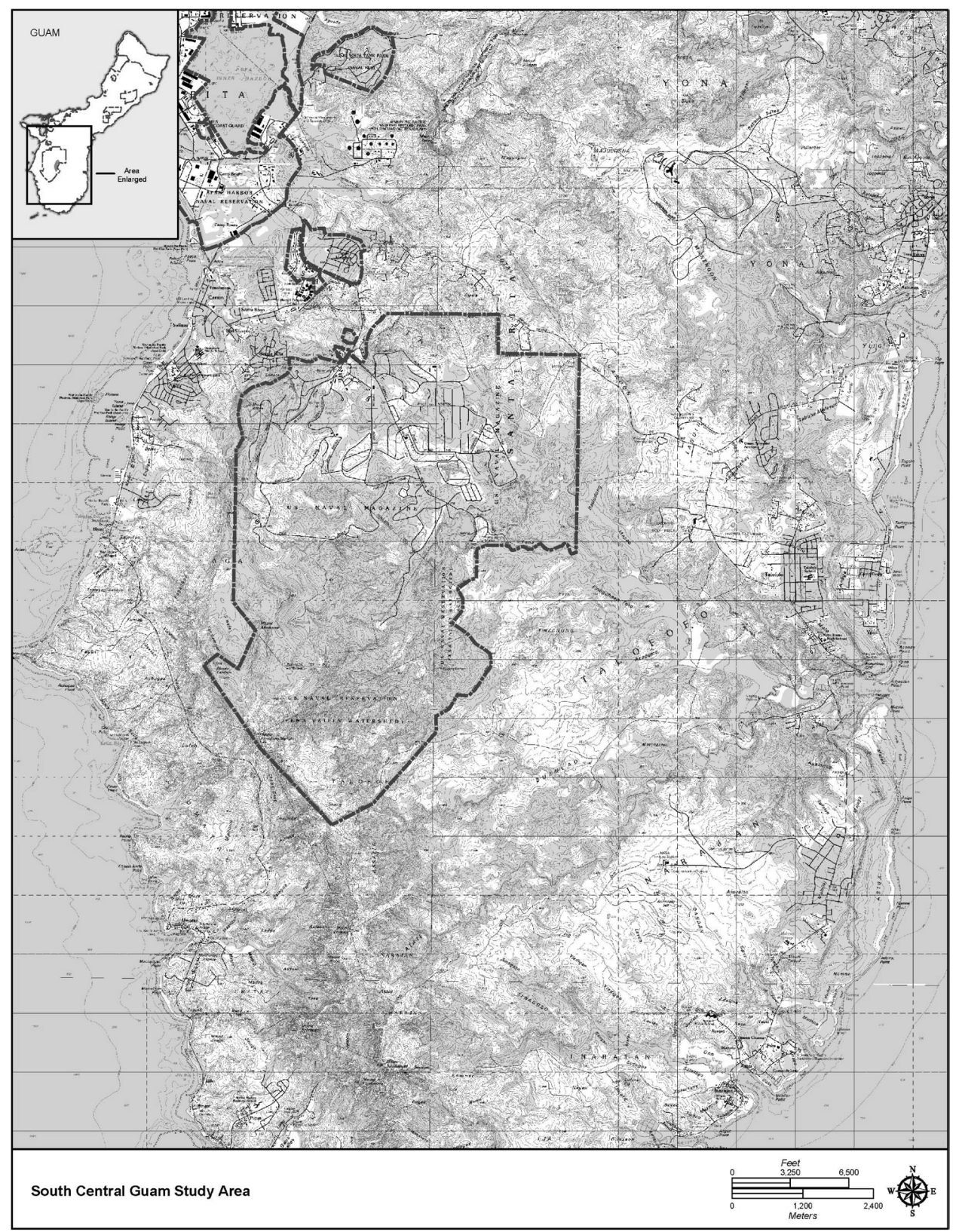

Fig. 2. Location of the Naval Ordnance Annex and Waterfront Annex on Guam.

Ordnance Annex on the island of Guam (Allen et al. 2002). The irregularly shaped Naval Ordnance Annex occupies a large, hilly, inland area southeast of Apra Harbor (Craib and Yoklavich 1996; Henry et al. 1998a, 1998b; Fig. 2). It has a rugged karst topography. (Archaeological site numbers and locations are not presented here for their protection, but data relevant to the discussion below are presented in Table 1.) 
Table i. Naval Ordnance Annex Sites used by World War II Japanese Infantry and STRAGGLERS.

\begin{tabular}{|c|c|c|}
\hline SITE TYPE & $\begin{array}{l}\text { NUMBER OF } \\
\text { FEATURES }\end{array}$ & WORLD WAR II JAPANESE ARTIFACTS \\
\hline Rockshelter & 11 & $\begin{array}{l}\text { A metal storage tube top, copper screening, a brass button, and a } \\
\text { ceramic potsherd. }\end{array}$ \\
\hline Rockshelter & 8 & $\begin{array}{l}\text { U.S. ordnance canister and lid, metal saw blade fragments, segments } \\
\text { of rubber tire with hand-drilled holes, bailing wire, a clear glass jar, } \\
\text { fragments of sheet metal, and small bits of paper printed with } \\
\text { Japanese characters adhered to a Tridacna shell. }\end{array}$ \\
\hline Rockshelter & 2 & $\begin{array}{l}\text { Leather shoe fragments, a blue plastic U.S. Marine Corps button, } \\
\text { Japanese bottles, an iron wok, a porcelain jar, and metal fragments. }\end{array}$ \\
\hline Cave complex & 4 & $\begin{array}{l}\text { Rubber tire inner tube, a wooden staff with forked ends, a broken } \\
\text { spotlight, 1/16-inch wire mesh, the base of an oval U.S. mess kit, a } \\
\text { small jar with wooden lid, a clear screw-topped jar, a metal storage } \\
\text { tube with two green canvas tarps modified by white stitching, and } \\
\text { pig and deer bones. }\end{array}$ \\
\hline Rockshelter & 2 & Metal cooking pots and utensils. \\
\hline Cave & 1 & Bullet casings, an ammunition clip, and a military button or snap. \\
\hline Rockshelter & 1 & $\begin{array}{l}\text { Cut log seats, a length of bamboo, burlap sacks, toothbrushes, a pair } \\
\text { of rubber tire slippers, a } 1945 \text { 10-ounce Coca-Cola bottle } \\
\text { manufactured in Oakland, a metal rod, four colored pencils (green, } \\
\text { blue, and red) each split in half with the lead missing, leather shoe } \\
\text { fragments, a metal washer, metal wire, } 20 \mathrm{~mm} \text { and M1 bullet } \\
\text { casings, small U.S. (Abbott Laboratories) and Japanese medicine } \\
\text { bottles, a trenching tool fragment, a mess kit lid, a tarp fragment } \\
\text { and grommet, a Barbasol shaving cream tube, a metal pickaxe blade, } \\
\text { buttons (one stamped "US Marine Corps"), and a plastic bottle cap. }\end{array}$ \\
\hline Rockshelter & 4 & $\begin{array}{l}\text { World War II-era Coca-Cola, beer, condiment, and liquor bottles, } \\
\text { and pig bones. }\end{array}$ \\
\hline $\begin{array}{l}\text { Cave and } \\
\text { rockshelter }\end{array}$ & 2 & $\begin{array}{l}\text { Metal shrapnel, leather shoe soles, bullet casings, washers, medicine } \\
\text { bottles, a mess kit lid inscribed "New Georgia, Samoa," a } 1944 \\
\text { Coca-Cola bottle, two Pulaski clearing axes, window glass, a } 250 \mathrm{ml} \\
\text { tube of McCormick's iron glue, a tarp eyelet, a large piece of folded } \\
\text { cloth, a tin can, a metal ammunition box, a cut log seat, forked } \\
\text { sticks, and a torch fragment in a niche. }\end{array}$ \\
\hline Cave & 7 & $\begin{array}{l}\text { An ammunition can, a mess kit cup, tin cans, leather boot soles, and } \\
\text { enameled metal bowls. }\end{array}$ \\
\hline $\begin{array}{l}\text { Terraces and } \\
\text { cave }\end{array}$ & 3 & $\begin{array}{l}\text { U.S. ordnance canisters, leather shoe sole impressed with "Danbury," } \\
\text { military helmet fragment, broken cooking pot, wire mesh, and a } \\
\text { brown glass bottle with embossed "K" on its base. }\end{array}$ \\
\hline
\end{tabular}

A 1998 survey of one area recorded one rockshelter containing a metal storage tube top, copper screening, a brass button, a nontraditional ceramic potsherd, and four foxholes with sandbags, the latter presumably dating to post-World War II U.S. military exercises (Allen et al. 2002). Another rockshelter revealed the remains of a World War II-era U.S. ordnance canister and lid, metal saw blade fragments, segments of rubber tire with hand-drilled holes, bailing wire, a clear glass jar, fragments of sheet metal, and small bits of paper printed with Japanese characters adhering to a 


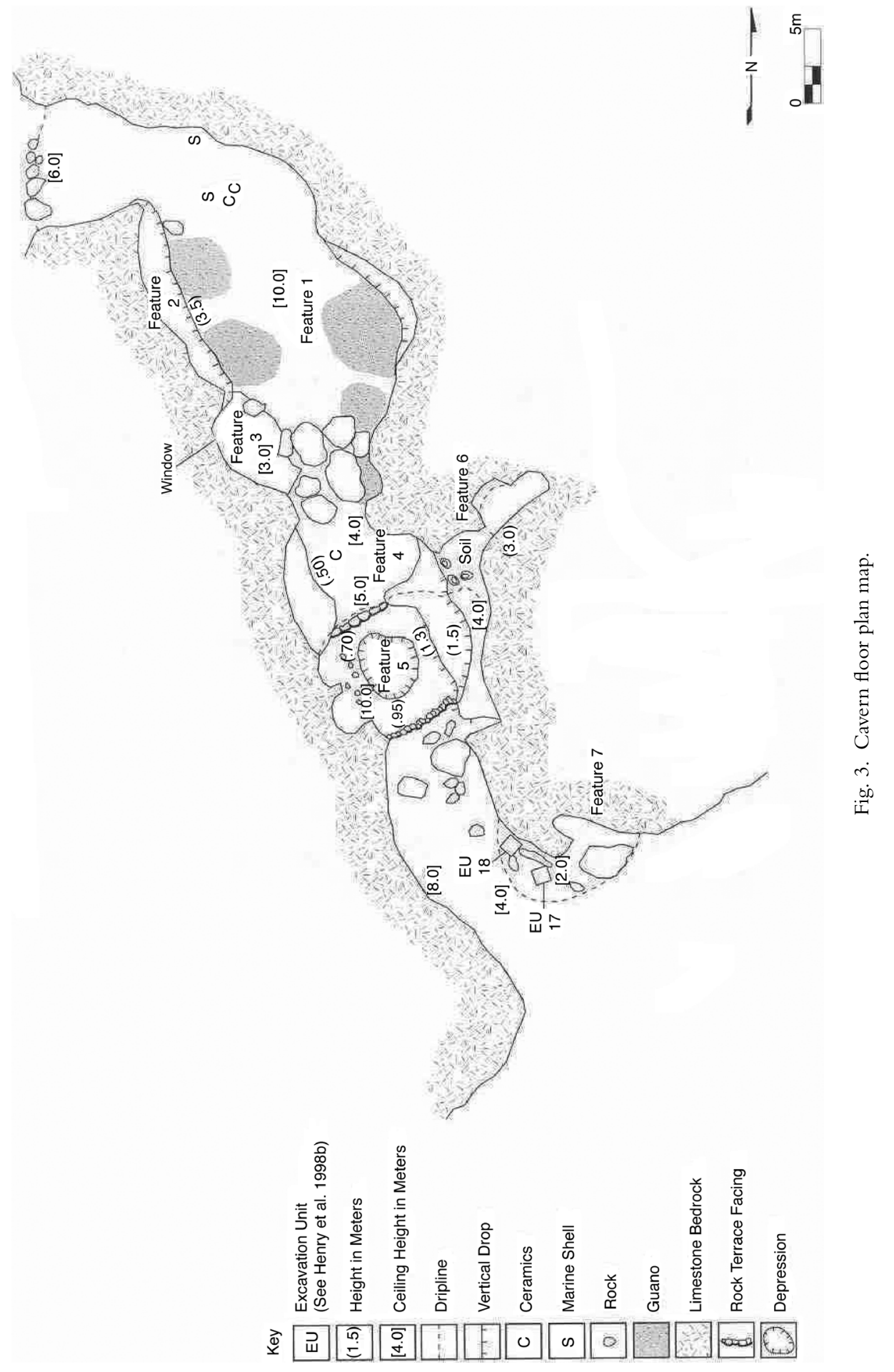


Tridacna shell. A set of natural terraces and small caves nearby contained three U.S. ordnance canisters, a leather shoe sole impressed with the name "Danbury," a military helmet fragment, a broken cooking pot, wire mesh, and a brown glass bottle embossed with "K" on its base. Mounded limestone rock piles and crude walls on the surface at all three locations suggested modification for use as a shelter during or after the U.S. invasion (Allen et al. 2002).

Between January and May of 2002, Pacific Consulting Services, Inc. (PCSI; formerly Ogden Environmental and Energy Services, Inc.) conducted a second archaeological survey for the U.S. Navy of four additional parcels within the U.S. Naval Ordnance Annex (Gosser et al. 2003). The archaeological remains recorded in the 2002 survey area were located northeast of Fena Reservoir. Elevations of these sites ranged between 24 and 52 meters above sea level (masl). This most inaccessible portion of the Naval Ordnance Annex consists of deep limestone sinkholes with high narrow ridges containing shallow rockshelters and caves that provided ideal refuge and lookout points for World War II Japanese soldiers and stragglers. The steep northsouth trending limestone ridges with sinkholes and caves used by the stragglers were protected to some degree by the Maemong and Mahlac Rivers, which were interconnected by marshes. The area was bordered by rolling hills and fewer sinks (only occasionally used by Japanese stragglers) bracketed by the Maagas and Mahlac Rivers to the northeast and marshes above the Maemong and Tolaeyuus Rivers to the northwest.

Eight archaeological sites in this area contained evidence of World War II Japanese occupation presumably postdating the U.S. invasion in July of 1944 (see Table 1). One of the sites had previously recorded evidence of prehistoric habitation (Henry 1998b). Three sites consisted of natural caves that were modified by low rock walls around their entrance for defense; low platforms within provided sleeping quarters and cooking areas (Figs. 3 and 4). Smaller rockshelters provided less habitation space but higher visibility; these could have been used as lookout points for Japanese stragglers observing American and Chamorro patrols (Figs. 5-7). It is assumed that dense native vegetation was left in front of both site types to obscure entrances during use.

As listed in Table 1, artifacts left at these sites by World War II Japanese infantry and stragglers were mostly of American manufacture (Figs. $8 \mathrm{a}$ and $8 \mathrm{~b}$ ) or Japanese modification (Fig. 9). They consisted of clothing (i.e., leather shoes, rubber tire sandals, and metal uniform buttons), glass bottles (for medicine, condiments, beer, sake, and liquor), Japanese cooking gear (metal woks), U.S. military cooking gear (metal pots, bowls, mess kits, and utensils), tools (i.e., headlamps, pickaxes, clearing axes, and trenching tools), U.S. military shelters (tarps and their storage tubes), personal items (i.e., shaving cream, toothbrushes, and pencils), cloth (i.e., burlap bags), and weaponrelated supplies (i.e., bullet casings, clips, and ammunition boxes).

Several of these refuge sites contained evidence of World War II-era fire pits or cobble hearths, presumably used for cooking at night to avoid detection. Faunal food remains were also present in some of these caves and rockshelters, indicating that Japanese infantry and stragglers were trapping or hunting pigs and deer, both species introduced historically to the island.

\section{ETHNOGRAPHIC EVIDENCE}

The fact that Japanese stragglers were still living in what is today the Naval Ordnance Annex and other areas of Guam did not go unnoticed by the American military ad- 


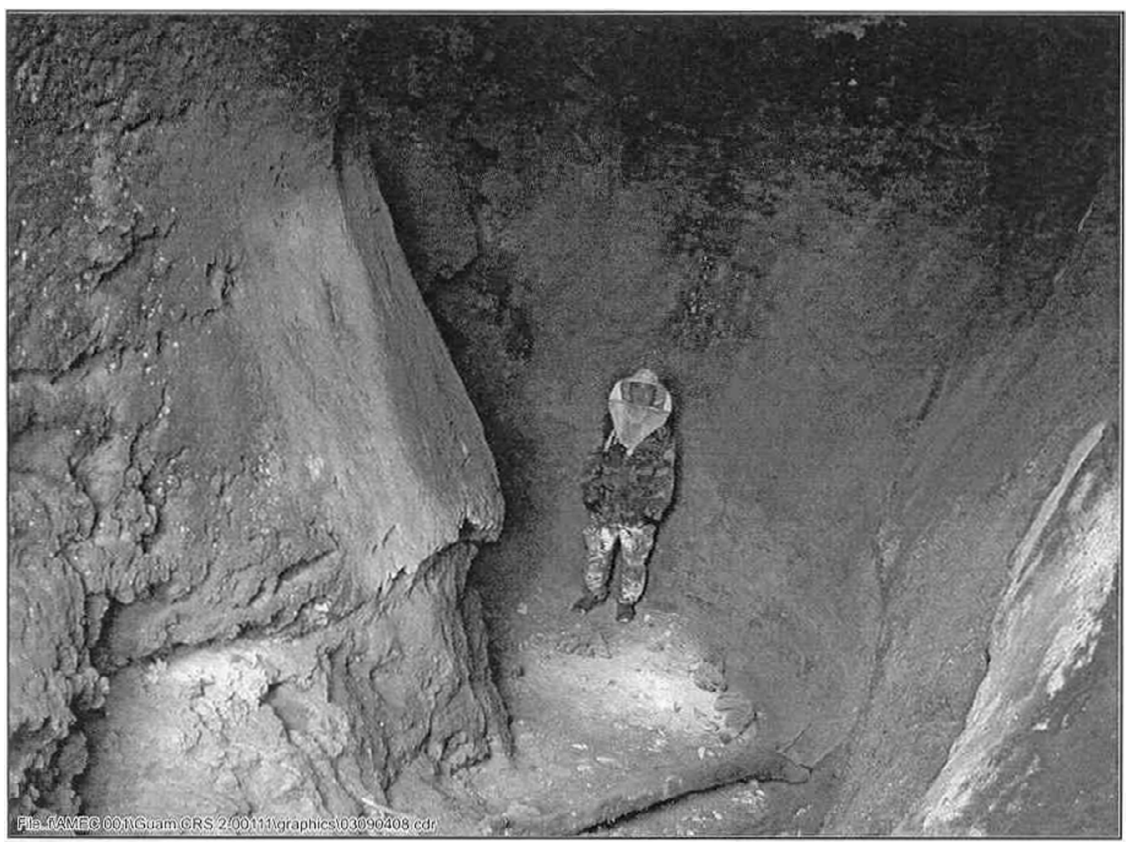

Fig. 4. Cavern interior, modification in the foreground.

ministration or the Japanese foreign office after World War II. A volunteer corps of armed Chamorro civilians called the Guam Combat Patrol was formed in 1945 to ferret out just such stragglers with U.S. Marine assistance (Fig. 10). Many of these Chamorro had personal reasons for taking no captives in pursuance of their duties. Although small groups of Japanese stragglers stayed mobile and tried to avoid leaving evidence of their passing, hunger and desperation sometimes drove them to take risks (Hatashin 2009). Several Chamorro civilians had disappeared under suspicious circumstances over the years - presumed killed by Japanese still hiding in the jungle (Rogers 1995). Severe treatment and torture of Chamorro civilians in the days leading up to the U.S. invasion had engendered resentment toward Japanese military survivors that did not wane in the succeeding decades.

In 1953, Operation Straggler was launched in southern Guam by the U.S. military, with Japanese assistance: "Packages were left in caves, posters were nailed to trees, and a Navy plane dropped fifteen thousand leaflets" (Kahn 1962:21). Nobody was found and nobody surrendered following this campaign, however. Then, in 1957, some offduty Marines on what is today called a "boonie stomp" found a campsite with cooking gear and hand tools. Naval Intelligence then posted on-duty Marines to patrol the area; they found sleeping pads made of palm fronds, Japanese tabi (split-toed socks), chopsticks, a toothbrush with the Japanese Navy emblem, hacksaw blades, files, a saw, cooking pots and pot holders, a pestle, a jar of oil, a glass bottle, and a crude twowheeled cart. A few months later, an American woman noticed a scrawny, long-haired person disappearing into the rough at the Windward Hills Golf and Country Club, two miles east of the Navy Magazine (today's Ordnance Annex). It was not until 1960, however, that two Chamorro hunters near the golf course captured one of the 


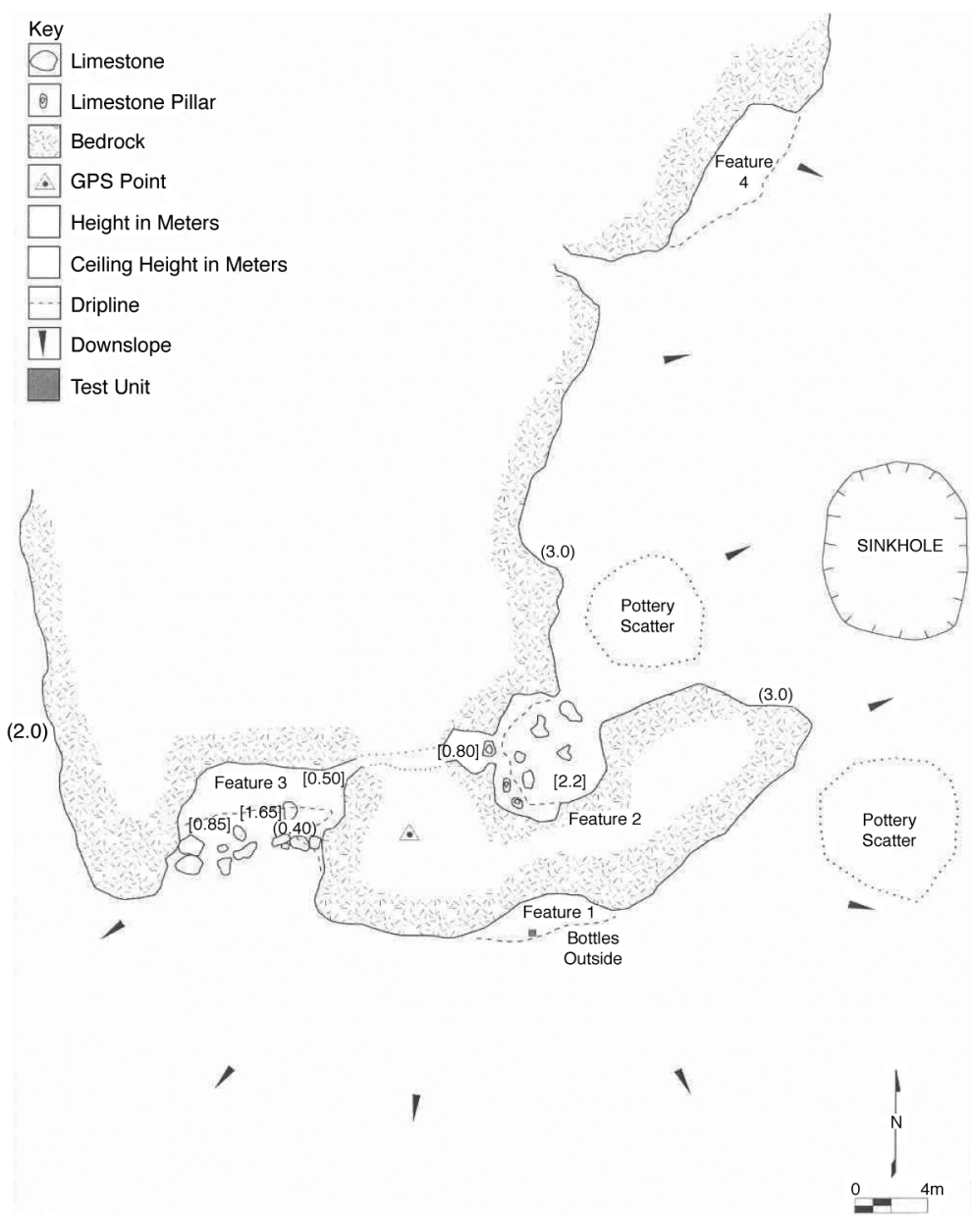

Fig. 5. Rockshelter floor plan map.

stragglers named Minagawa. With his help, his companion Ito later surrendered (Kahn 1962).

According to these captives, most stragglers maintained the rudiments of military order, although individual differences emerged in the face of deteriorating health and evidence that the war had not fared well for the Japanese. Savvy stragglers avoided smoking American cigarette butts, burning fires during daylight, or stripping trees of their fruit for fear of giving away their position. The hunt for sustenance was a daily chore; after capture, other Japanese troops mentioned eating roots, frogs, and snails (Hatashin 2009). Besides foraging, Minagawa and Ito visited a U.S. Army dump every week, filling their homemade knapsacks with "empty cans and bottles, broken shovels and eating utensils, yards of mosquito netting, rags to patch their clothes with or to unravel for thread, bedsprings to convert into needles, and empty cartridge cases to turn into thimbles" (Kahn 1962:47). Some members of the Combat Patrol shot 


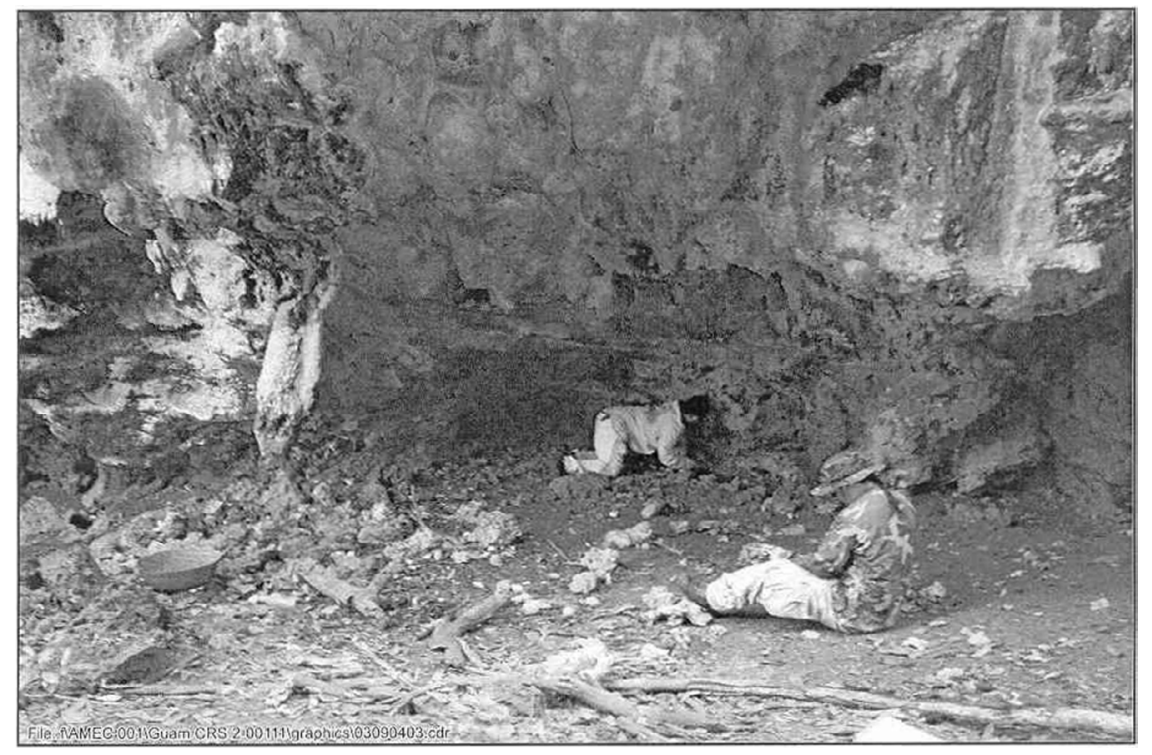

Fig. 6. Rockshelter, metal wok on the left.

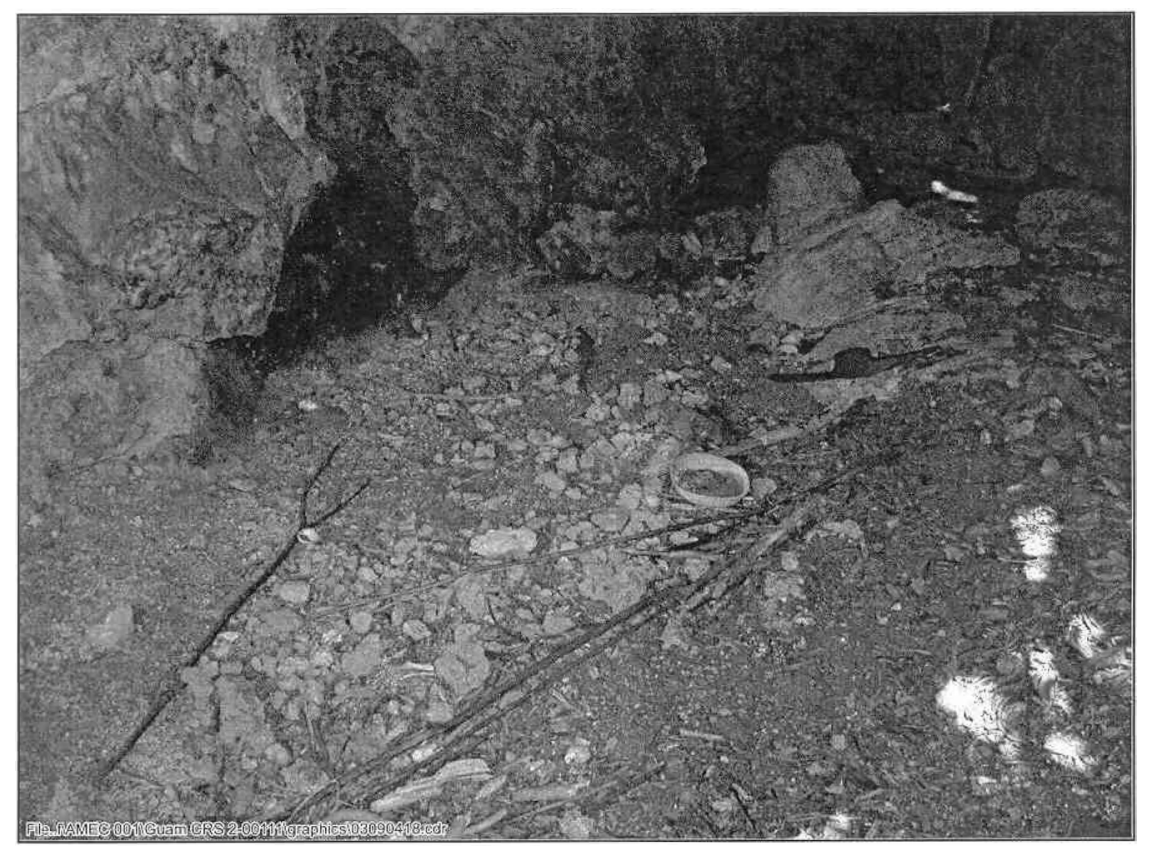

Fig. 7. Rockshelter, pickaxe and bowl in background. 


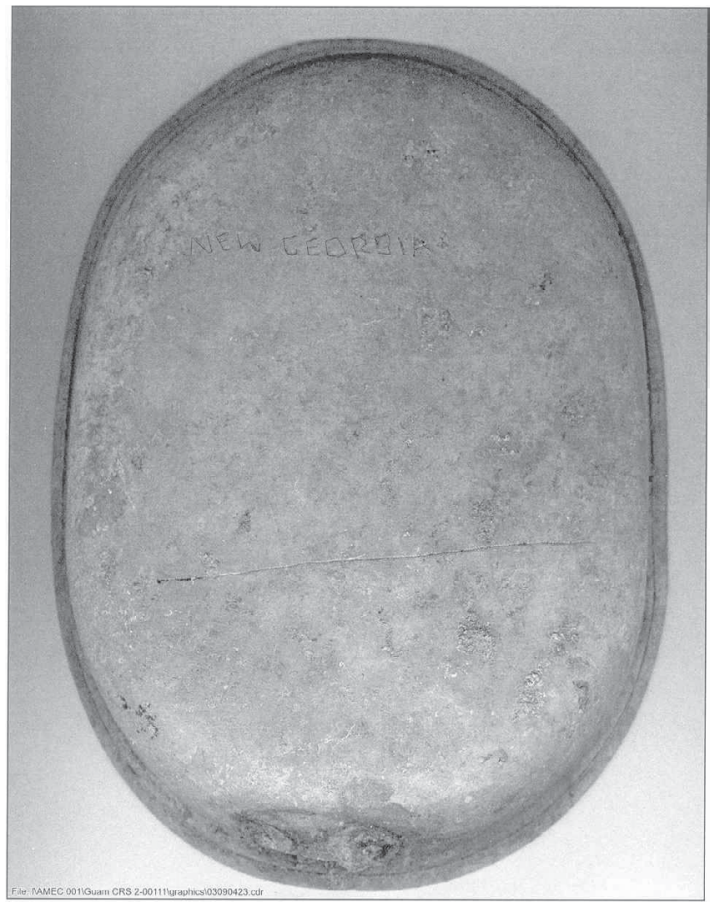

A

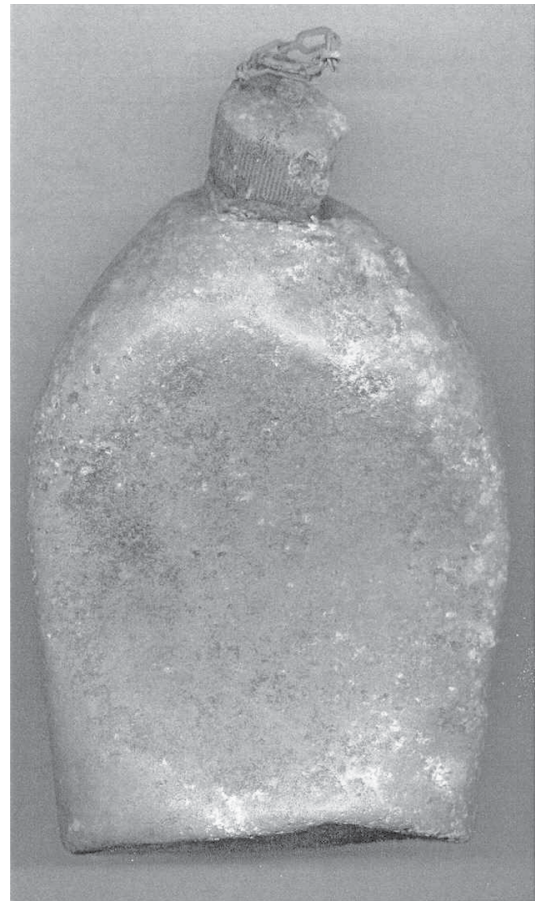

B

Fig. 8. A. U.S. metal mess kit with "New Georgia" inscribed. B. U.S. metal canteen with "1918” inscribed.

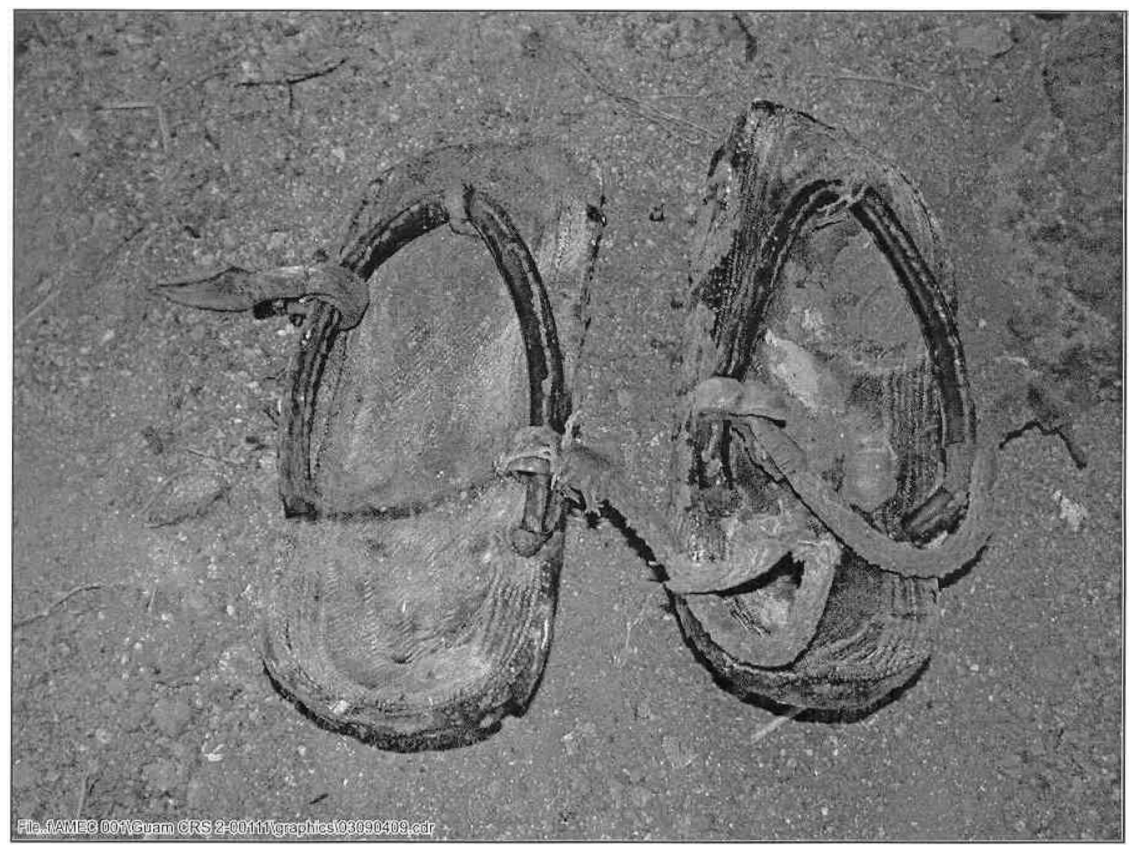

Fig. 9. Rubber tire sandals. 


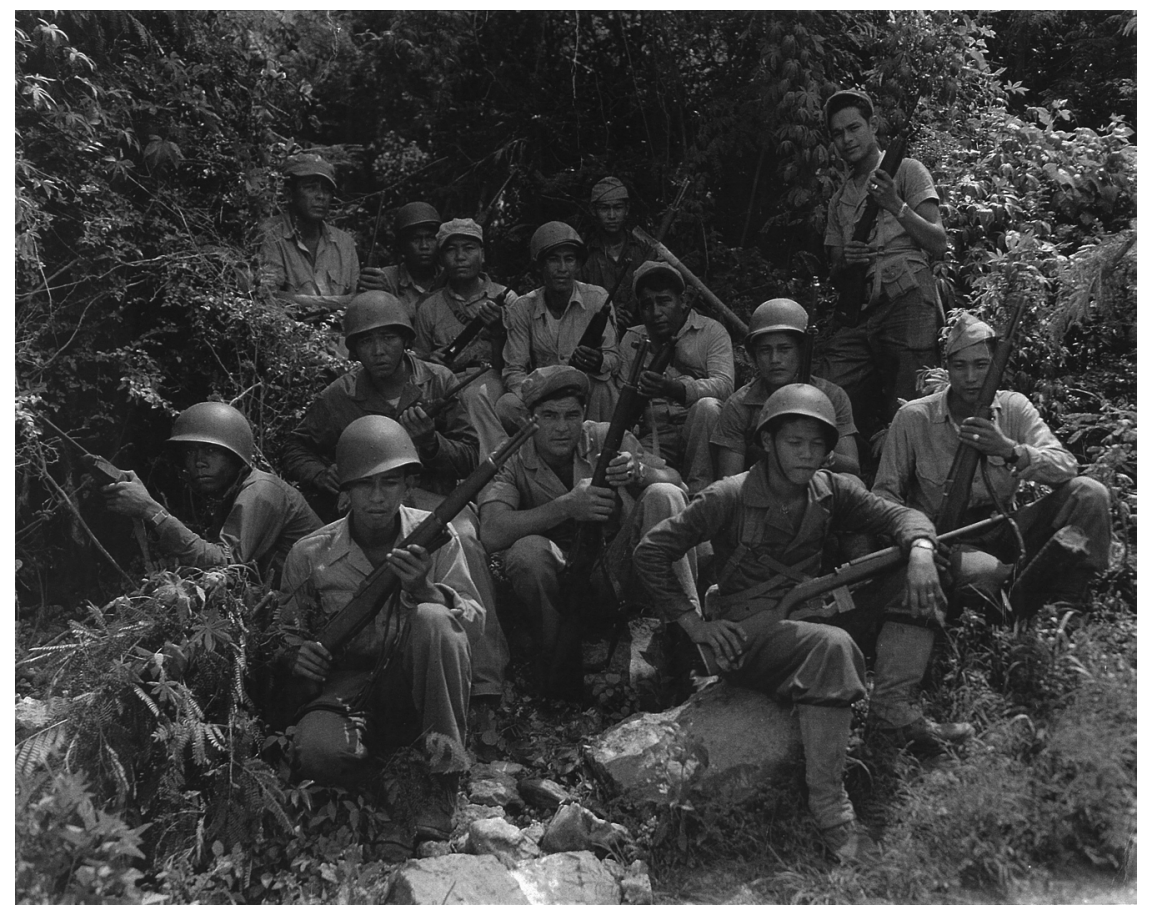

Fig. 10. Guam Combat Patrol circa 1945. (Courtesy of Lon Bulgrin)

bullet holes into objects before throwing them away, so that they could not be reused as cooking vessels by the ingenious stragglers (Hatashin 2009).

In 1972, the final Japanese straggler, Sergeant Shoichi Yakoi, was captured by two Chamorro hunters while he was setting shrimp traps approximately 5 miles inland from Talofofo, southeast of the Naval Ordnance Annex (Rogers 1995). A tailor by profession, Yakoi had fashioned his own clothing and shoes from the bark of the native hibiscus tree (Pago) using bamboo needles. He later said he used a wine bottle base and gunpowder from rifle shells to start fires, cooked in a steel helmet using coconut oil for lighting and a condiment, made pig traps out of hibiscus bark ropes and barbed wire, patched his clothes with tanned toad leather, and made hand tools from U.S. bombshell fragments (Hatashin 2009). He also hand-dug an almost $3 \mathrm{~m}$ deep refuge tunnel. The tunnel was later found to contain reed traps he had built to catch rats and cats to supplement his diet of boiled Federico palm nuts, coconuts, spiny yams, poisonous toads, shrimp, eels, and catfish, all of which he cooked underground. ${ }^{2}$

\section{CONCLUSIONS}

After comparing World War II Japanese straggler archaeological sites in the Naval Ordnance Annex on Guam with the ethnographic record of the few soldiers who survived this ordeal, it seems reasonable to hypothesize that those sites with larger and 


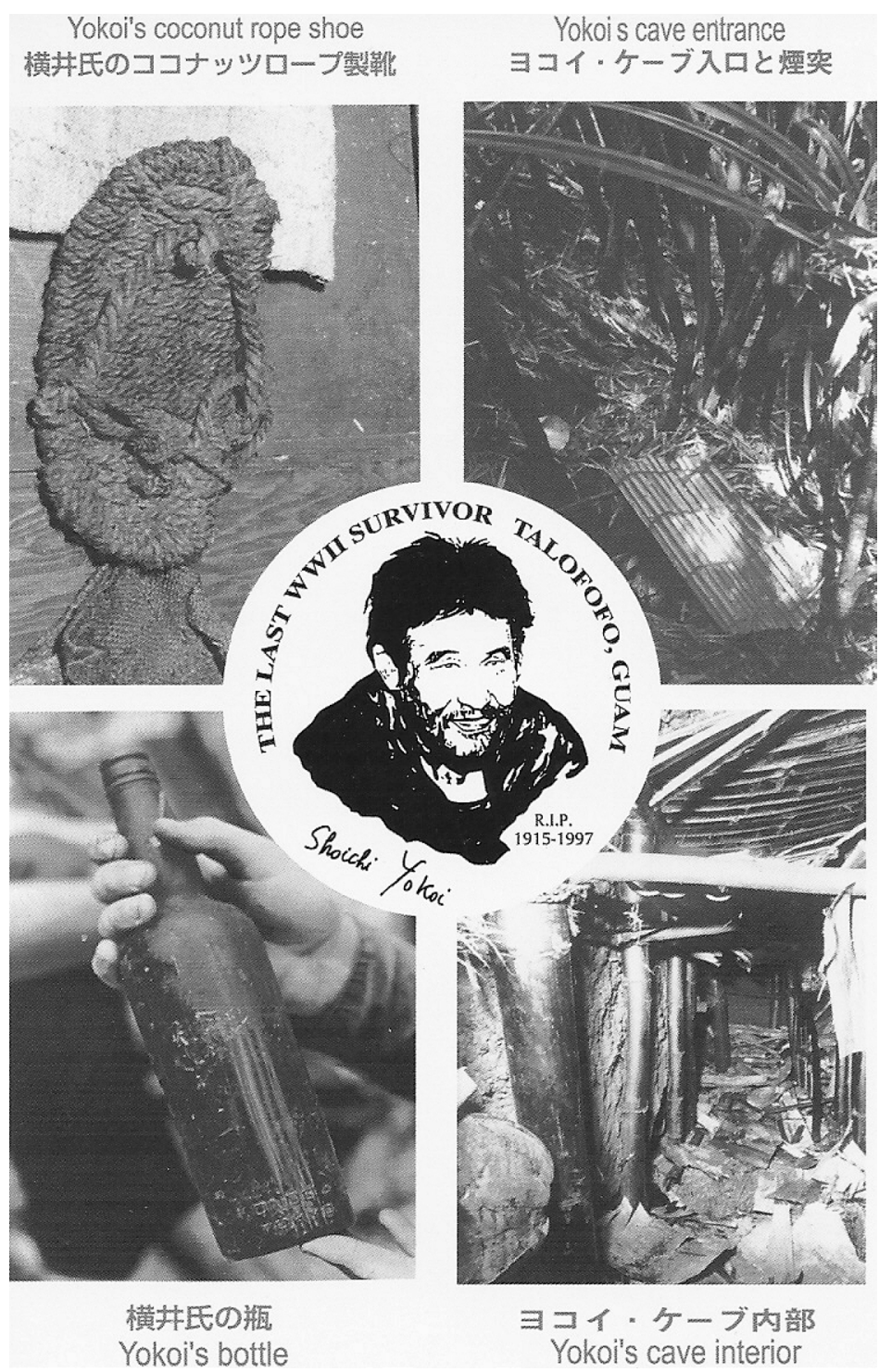

Fig. 11. Yokoi postcard.

more varied artifact assemblages than other sites were likely used by larger groups of infantry, for longer periods, or both. These sites might also represent the refuges of Japanese military officers such as Takeda who would presumably have accrued more items of higher value by virtue of his rank. In contrast, sites with smaller and less varied assemblages more likely represent smaller groups of stragglers who held no command positions, or were used for overnight stays while foraging.

Materials at sites with more artifacts were often hidden in crevasses of the cave systems or rockshelters, apparently in anticipation of return visits. The more scattered 
remains at sites with fewer artifacts suggest perhaps stragglers had made only one or two visits there and did not anticipate the necessity to hide evidence of their visit from U.S. Marine or Chamorro patrols; alternatively, these scattered remains could represent a hasty retreat. The almost complete absence of ammunition or weaponry at these sites in the Naval Ordnance Annex suggests both the desperate state of the stragglers and that they surrendered in full possession of the few arms they had retained; the latter is a tribute to their military discipline. ${ }^{3}$ While not denying the inexcusable atrocities committed by Japanese military on Chamorro, Okinawan, and Korean civilians, especially in the last days of World War II, these particular latter-day Bushido warriors had indeed proved to themselves that they possessed "true courage to live when it is right to live, and to die only when it is right to die."

\section{ACKNOWLEDGMENTS}

Numerous individuals on Guam and in Hawai' $i$ made the outcome of this project possible, through its permutations as Ogden Environmental, AMEC, and now Pacific Consulting Services, Inc. Difficult and at times hazardous field conditions were met with good humor, professionalism, and tenacity by the Ogden archaeological field supervisors Laura Gilda and Tony Torres, and field crew Christa Torres and Reid Yamasato. Boyd Dixon was the Project Director and Dennis Gosser was the Principal Investigator. Chuukese assistants Velix Fiten and Jeff Esefar of Guam Tropical Landscaping provided very cheerful field labor and daily lessons in Micronesian jungle survival.

Archaeologist Jeannette Simons, who was a Cultural Resources Specialist at Naval Facilities Command Pacific, Pearl Harbor in Hawai'i, made several very helpful in-field checks on Guam and provided critical guidance during report production. Archaeologist Jennings Bunn, then a Cultural Resources Specialist at Naval Facilities Command Marianas on the U.S. Naval Base in Guam, provided a comprehensive orientation to the project area and vital information related to World War II-era features, and was a source of unfailing enthusiasm for all things Guamanian.

Staff at the Honolulu office of PCSI including friend and colleague Stephan Clark, Douglas Hazelwood, and Lisa Holloway generously supplied moral and professional support during fieldwork and report production. Mary Riford, Scott Williams, and Constance O'Hare supervised the identification of traditional non-ceramic artifacts and non-shell faunal remains. William Montgomery assisted with computers, while Ui Naka'ahiki and Tony Torres produced the figures and Gregg Yanagi aided in report production.

Background information regarding the project area was obtained on Guam through the assistance of numerous individuals. Staff at the Richard Flores Taitano Micronesian Area Research Center and the Navy Public Works Center helped locate and copy historical maps and photographs. Linda Aguon, Vic April, and Tony Ramirez of the Guam Department of Parks and Recreation, Historic Resources Division provided site numbers and Chamorro translations of traditional place names. Maria Flores of the Bureau of Planning assisted with air photographs and Vic Torres was yet another source of unfailing enthusiasm for all things Chamorro.

\section{NOTES}

1. Note that the suicidal bansai or suicidal charges on U.S. troops after the invasion of each island in the Marianas were not honorable examples of the Bushido Code, however gloriously they may have been portrayed to Japanese soldiers by their officers at the time (Russell 2002). The suicidal kamikazi (lit. "divine wind") policy of air warfare that accompanied the subsequent U.S. invasion of Okinawa was also an act of desperation embraced by a military command that had abandoned its ancient moral compass (Behr 1989). "There was no greater perverter of Bushido than [the wartime Japanese Prime Minister, Hideki] Tojo” (Lamont-Brown 1998:63). 
2. A recreation of this tunnel is now a tourist attraction visited by many Japanese and American tourists on Guam.

3. In a similar demonstration of this discipline on the Commonwealth of the Northern Mariana Island of Saipan, Captain Oba Sakae surrendered his remaining 46 Japanese soldiers on December 1, 1945, after firing a final volley over the graves of their fallen comrades, then donning fresh uniforms carefully preserved for the occasion and marching out of the hills singing an old Japanese infantry song (Jones 1986).

\section{REFERENCES CITED}

Allen, J., B. Dixon, K. Aronson, D. Gosser, L. Gilda, T. Moorman, C. O’Hare, M. Riford, and J. TOENGES

2002 Archaeological Survey and Excavations at Naval Ordnance Annex, Territory of Guam. Report prepared for the U.S. Department of the Navy. Honolulu: Ogden Environmental and Energy Services, Inc.

Ballendorf, D., And M. Bartlett

1997 Pete Ellis An Amphibious Warfare Prophet 1880-1923. Annapolis: Naval Institute Press.

BeLlWOOD, P.

1979 Man's Conquest of the Pacific. New York: Oxford University Press.

BEHR, E.

1989 Hirohito Behind The Myth. New York: Villard Books.

BENFEY, C.

2003 The Great Wave Gilded Age Misfits, Japanese Eccentrics, and the Opening of Old Japan. New York: Random House.

BLAZ, B.

2008 Bisita Guam: Let Us Remember Nihi Ta Hasso. MARC Educational Series No. 30, Mangilao: University of Guam.

BroOKe, G., JR.

1986 John M. Brooke's Pacific Cruise and Japanese Adventure, 1858-1860. Honolulu: University of Hawai'i Press.

Burns, J.

2008 Underwater Archaeology Remote Sensing Survey of the Proposed AAV and LCAC Landing Beaches, Territory of Guam, Main Base (Dadi and Tipalao), and Tinian, (Unai Chulu and Unai Dangkulo), Commonwealth of the Northern Mariana Islands. Tampa: Southeastern Archaeological Research, Inc.

Craib, J., And A. Yoklavich

1996 Cultural Resources Management Overview Survey. U.S. Naval Computer and Telecommunications Area Master Station, Western Pacific (NCTAMS WESTPAC). Prepared for Department of the Navy, Pacific Division, Pearl Harbor, Hawai'i. Honolulu: Ogden Environmental and Energy Services Company, Inc.

Denfield, C.

1997 Hold the Marianas: The Japanese Defense of the Mariana Islands. New York: White Mane Publishing Company, Inc.

2002 Japanese World War II Fortifications and Other Military Structures in the Central Pacific. Saipan: N.M.I. Division of Historic Preservation.

Dixon, B.

2004 The archaeology of rural settlement and class in a pre-WWII Japanese plantation on Tinian, Commonwealth of the Northern Mariana Islands. International Journal of Historical Archaeology $8(4): 281-299$.

Dixon, B., S. Athens, J. Ward, T. Mangieri, and T. Reith (with contributions by W. Dickinson,

T. Dye, J. Liston, and G. Murakami)

1999 Archeological Inventory Survey of the Sasa Valley and Tenjo Vista Fuel Tank Farms, Piti District, Territory of Guam, Mariana Islands. Report prepared for the U.S. Department of the Navy. Honolulu: International Archaeological Research Institute, Inc.

Fritz, G.

2001 The Chamorro: A History and Ethnography of the Mariana Islands. Occasional Historical Papers Series, No. 1. Saipan: CNMI Division of Historic Preservation. 
Fukami, T., AND W. Cross

1969 The Lost Men of Anatahan. New York: Paperback Library.

Gailey, H.

1988 The Liberation of Guam 21 July-10 August 1944. Novato, Calif.: Presidio Press.

Gosser, D., B. Dixon, L. Gilda, and R. Nees (with contributions by J. Amesbury, D. Moore,

G. Murakami, L. Scott-Cummings, M. Haslam, A. Crowther, and T. Loy)

2003 Archaeological Survey and Limited Subsurface Excavations at the Naval Ordnance Annex and Waterfront Annex, Territory of Guam. Report prepared for the U.S. Department of the Navy. Honolulu: Pacific Consulting Services, Inc.

HANE, M.

1982 Peasants, Rebels, \& Outcasts The Underside of Modern Japan. New York: Pantheon Books.

Hatashin, O.

2009 Private Yokoi's War and Life on Guam, 1944-1972: The Story of the Japanese Imperial Army's Longest WWII Survivor in the Field and Later Life. Folkstone: Global Oriental.

Henry, J., A. Haun, M. Kirkendall, and D. DeFant

1998a Final Report: Phase I Archaeological Survey and Subsurface Testing, US Naval Activities Ordnance Annex, Guam, Volumes I and II. Prepared for Department of the Navy, Pacific Division, Naval Facilities Engineering Command, Pearl Harbor, Hawai'i. Hilo: Paul H. Rosendahl, Ph.D., Inc.

1998 Final Report: Phase II Archaeological Survey and Subsurface Testing, US Naval Activities Ordnance Annex, Guam. Prepared for Department of the Navy, Pacific Division, Naval Facilities Engineering Command, Pearl Harbor, Hawai'i. Hilo: Paul H. Rosendahl, Ph.D., Inc.

Higuchi, W.

1997 A History of Pre-War Japanese Residents of Guam. In Guam History: Perspectives Volume One, 141-180, ed. L. Carter, W. Wuerch, and R. Carter. Richard F. Taitano Micronesian Area Research Center, Mangilao: University of Guam.

2000 Japanese Military Occupation of Guam, 1941-1944. Unpublished Master's thesis, Micronesian Studies, Mangilao: University of Guam.

INEAGA, S.

1978 The Pacific War 1931-1945: A Critical Perspective on Japan's Role in World War II by a Leading Japanese Scholar. New York: Pantheon Books.

JeNNiSON-Nolan, J.

1980 Land and Lagoon Use in Prewar Guam: Agat, Piti, and Asan. MARC Working Papers No. 15, Micronesian Area Research Center, Mangilao: University of Guam.

JONES, D.

1986 Oba The Last Samurai Saipan 1944-1945. Novato: Presidio Press.

KAHN, E. J., JR.

1962 The Stragglers. New York: Random House.

LAMONT-BROWN, R.

1998 Kempeitai Japan's Dreaded Military Police. Frome: Sutton Publishing Limited.

LobBan, C., AND M. SCHefTeR

1997 Tropical Pacific Island Environments. Mangilao: University of Guam Press.

LODGE, O. R.

1954 The Recapture of Guam. Historical Branch, G-3 Division Headquarters, Washington, D.C.: U.S. Marine Corps.

Martinez, D.

2004 Identity and Ritual in a Japanese Diving Village: The Making and Becoming of Person and Place. Honolulu: University of Hawai'i Press.

MEYER, M.

1993 Japan: A Concise History. Lanham: Roman \& Littlefield Publishers.

Nitobe, I.

2006 Bushido: The Soul of Japan. Stepney, Australia: Axiom Publishing.

O'DONNELL, P.

2002 Into the Rising Sun In Their Own Words: World War II's Pacific Veterans Reveal the Heart of Combat. New York: The Free Press. 
ONODA, H.

1974 No Surrender My Thirty-Year War. Tokyo: Kodansha International Ltd.

Palomo, T.

1984 An Island in Agony. Guam: (printed by author).

Peattie, M.

1988 Nanyo: The Rise and Fall of the Japanese in Micronesia 1885-1945. Honolulu: University of Hawai'i Press.

ROGERS, R.

1995 Destiny's Landfall: A History of Guam. Honolulu: University of Hawai'i Press.

RotTMAn, G.

2004 Guam 1941 \& 1944 Loss and Reconquest. Westminster: Osprey Publishing.

RuSSELL, L.

2002 The Knights of Bushido: A Short History of Japanese War Crimes. London: Greenhill Books.

RuSSELL, S.

1998 Tiempon I Manmofo 'na: Ancient Chamorro Culture and History of the Northern Mariana Islands. Micronesian Archaeological Survey No. 32, Saipan: N.M.I. Division of Historic Preservation.

1999 Tiempon Aleman: A Look Back at the German Rule of the Northern Mariana Islands 1899-1914. Saipan: N.M.I. Division of Historic Preservation.

SPENNEMANN, D.

1999 Aurora Australis: The German Period in the Mariana Islands 1899-1914. Occasional Historical Papers No. 5, Saipan: N.M.I. Division of Historic Preservation.

ThOMPSON, L.

1945 The Native Culture of the Marianas Islands. Bernice P. Bishop Museum Bulletin 185. Honolulu: Bishop Museum Press.

YOUNG, F. J.

1988 Soil Survey of the Territory of Guam. U.S. Department of Agriculture, Soil Conservation Service, Washington, D.C.: U.S. Government Printing Office.

\begin{abstract}
The U.S. invasion of the Micronesian island of Guam in July of 1944 ended the threeyear Japanese occupation of this American possession, and by August 10 all formal resistance was over. However, two companies of approximately 60 Japanese infantry still under military command were ordered by their officers to conduct guerilla warfare against American forces, while smaller groups of stragglers escaped into the rugged interior of the island to avoid combat. Recent archaeological surveys of the U.S. Naval Ordnance Annex revealed evidence of occupation of limestone rockshelters and caverns by one of these companies, who often utilized or modified items of American manufacture recovered from U.S. military dumps for their daily survival. The company's military commander eventually surrendered upon orders of the Emperor of Japan on September 4, 1945, but other stragglers on Guam survived for decades after World War II, the last being captured in 1972. The disciplined survival of organized World War II Japanese soldiers across the Pacific reflected the spirit of Bushido or Way of the Warrior, a feudal code of conduct embracing not only military behavior during battle, but the conduct of soldiers in all aspects of life. KeYwords: Guam, Oceania, World War II, Japanese, Bushido, warfare.
\end{abstract}

